\title{
Investigasi kapasitas kepemimpinan dalam kelompok peternak sapi PO Kebumen di pesisir Kabupaten Kebumen
}

\author{
Mochamad Sugiarto *, Oentoeng Edy Djatmiko, Syarifuddin Nur, Yusmi Nur Wakhidati \\ Fakultas Peternakan Universitas Jenderal Soedirman, Purwokerto, 53123 \\ *Correspondence: zoegic@yahoo.com
}

Received: December $8^{\text {th }}, 2019$; Accepted: Maret 19th, 2020 ; Published online: July 17th 2020

Abstrak

Tujuan: Keberlanjutan kelompok peternak sapi PO Kebumen di wilayah pesisir Kabupaten Kebumen menjadi sangat penting untuk menunjang peningkatan produksi sapi potong di pedesaan. Kapasitas kepemimpinan merupakan kemampuan ketua kelompok dalam mengelola kelompok dan anggotanya menuju kelompok peternak yang lebih dinamis. Kajian ini bertujuan mengidentifikasi kapasitas kepemimpinan ketua kelompok peternak sapi PO Kebumen dan menganalisis keterkaitan antara faktor demografi dengan kapasitas kepemimpinan ketua kelompok peternak sapi PO Kebumen.

Metode: Responden diambil sebanyak 147 peternak sapi PO Kebumen dengan menggunakan metode multistage sampling untuk memberikan penilaian terhadap kapasitas kepemimpinan ketua kelompok peternak sapi PO Kebumen. Data yang terkumpul dianalisis dengan statistik deskriptif dan korelasi ranking spearman.

Hasil: Hasil analisis menunjukkan bahwa umur ketua kelompok, pengalaman ketua kelompok terlibat dalam kelompok peternak, dan pengalaman ketua kelompok dalam beternak sapi potong memiliki hubungan yang nyata dengan kapasitas kepemimpinan dalam kelompok $(\mathrm{P}<0,05)$.

Kesimpulan: Ketua kelompok peternak sapi PO Kebumen memiliki kapasitas kepemimpinan yang tinggi.

Kata Kunci: Kapasitas kepemimpinan; Pengalaman beternak; Pengalaman berkelompok

\section{Abstract}

Objective: The sustainability of the Kebumen Ongole Grade cattle farmers groups in the coastal area of Kebumen Regency has become very important to support the increase in beef cattle production in the countryside. Leadership capacity is the ability of group leaders in managing groups and their members toward more dynamic groups of farmers. This study aimed to identify the leadership capacity of Kebumen Ongole Grade cattle farmers and analyze the relationship between demographic factors and the leadership capacity of Kebumen Ongole Grade cattle farmers.

Methods: One hundred forty-seven respondents of Kebumen Ongole Grade cattle farmers were taken using the multistage sampling method to provide an assessment of the leadership capacity of the head of Kebumen Ongole Grade cattle farmers group. The collected data were analyzed with descriptive statistics and Spearman rank correlation. 
Results: The analysis showed that the age of the group leader, the experience of the group leader involved in the farmers group, and the experience of the group leader in raising beef cattle has a significant relationship with the leadership capacity in the group $(\mathrm{P}<0.05)$.

Conclusions: The heads of the Kebumen Ongole Grade cattle farmers groups had high leadership capacity.

Keywords: Leadership capacity; Farming experience; Group experience

\section{PENDAHULUAN}

Usaha peternakan sapi PO Kebumen telah menjadi salah satu aktifitas ekonomi utama dalam pembangunan pedesaan di wilayah Kabupaten Kebumen bagian selatan yang meliputi Kecamatan Puring, Klirong, Petanahan, Ambal, Mirit dan Bulus Pesantren. Kecamatan tersebut merupakan wilayah utama pengembangan produksi peternakan sapi PO Kebumen. Introduksi sapi PO Kebumen yang dilakukan sejak tahun 2010, telah menumbuhkan pergerakan sosial ekonomi di masing masing keluarga dan lingkungan peternak sapi PO Kebumen. Pergerakan ekonomi tergambar dari peningkatan jenis usaha ekonomi dan pergerakan sosial terlihat dari peningkatan interaksi masyarakat melalui keberadaan kelompok peternak sapi. Sugiarto et al.[1] menyatakan bahwa kegiatan ekonomi usaha sapi PO Kebumen juga mengakibatkan tuntutan peningkatan pada kapasitas sumberdaya manusia dan organisasi/ kelompok peternak sapi PO Kebumen.

Pada tahun 2019, terdapat 95 kelompok perbibitan sapi PO Kebumen di wilayah utama perbibitan sapi PO Kebumen. Kelompok peternak telah menjadi media utama dalam mendistribusikan informasi dan inovasi peternakan dalam rangka meningkatkan produksi sapi PO Kebumen. Selain itu, kelompok peternak sapi PO Kebumen menjadi sarana interaksi sosial antar peternak yang dapat mendorong terwujudnya modal sosial yang kuat di masyarakat. Rustinsyah [2] menyatakan bahwa mata pencaharian peternak dapat semakin baik karena terbangunnya hubungan sosial secara internal dan eksternal. Hubungan secara internal dibangun di dalam kelompok peternak sapi potong. Namun demikian, keberadaan kelompok peternak sapi PO Kebumen menghadapi potensi ancaman berupa stagnasi dan ketidakberlanjutan. Stagnasi merupakan gambaran kelompok peternak yang tidak mengalami perkembangan secara signifikan dalam kurun waktu tertentu. Sedangkan ketidakberlanjutan merupakan dampak lanjutan dari stagnasi yang berakibat pada berakhirnya peranan kelompok untuk peningkatan produksi sapi PO Kebumen. Ketidakberlanjutan kelompok peternak juga disebabkan ketidakmampuan kelompok dalam beradaptasi dengan perkembangan perkembangan baru. Suheimi et al. [3] menyatakan bahwa perkembangan eksternal seperti perubahan pola komunikasi, kemampuan interaksi dengan pemerintah dan penyuluh, perubahan ketersediaan input produksi mendorong perubahan dinamika kelompok petani. Kemampuan kepemimpinan di dalam kelompok peternak akan sangat membantu kelompok peternak dalam menyesuaikan diri dengan perubahan perubahan internal dan eksternal kelompok peternak. Kepemimpinan dalam kelompok sangat diperlukan untuk kemudahan proses penyesuaian kelompok dengan perubahan perubahan internal dan eksternal. Uhl-Bien dan Arena [4] menyatakan proses adaptabilitas kelompok terhadap perubahan membutuhkan kepemimpinan yang memberikan ruang untuk munculnya ide ide anggota dan menginspirasi munculnya inovasi yang sesuai kebutuhan organisasi dan lingkungan.

Perkembangan kelompok peternak sapi PO Kebumen sangat ditentukan oleh kapasitas anggota dan ketua kelompok dalam mewujudkan tujuan kelompok. Ketua kelompok sebagai pemimpin dalam kelompok peternak menjadi variabel penting dalam menggerakkan kelompok peternak sapi PO Kebumen. Kapasitas kepemimpinan ketua kelompok merupakan kemampuan ketua kelompok untuk mendorong, 
mengarahkan, dan menginspirasi anggota secara bersama sama mencapai tujuan kelompok. Surji [5] menyatakan bahwa kepemimpinan merupakan keadaaan untuk mendengarkan dengan sungguh sungguh, memiliki pikiran yang menginspirasi untuk mengambil keputusan, menginspirasi anggota untuk mencapai serangkaian tujuan yang telah direncanakan. Penguatan kapasitas kepemimpinan dalam kelompok menjadi hal penting dalam mengembangkan dinamika kelompok yang berdampak pada kemampuan diversifikasi usaha dan peningkatan kegiatan kegiatan dalam kelompok peternak sapi PO Kebumen. Dubrin [6] menyatakan bahwa kelompok yang efektif membutuhkan kepemimpinan yang efektif dan kelompok akan sulit berkembang kalau mengabaikan hal tersebut. Terkait dengan hal tersebut, kajian ini bertujuan mengidentifikasi kapasitas kepemimpinan ketua kelompok peternak sapi PO Kebumen dan menganalisis keterkaitan antara umur peternak, tanggungan keluarga, pengalaman berkelompok, pendidikan, dan pengalaman beternak dengan kapasitas kepemimpinan ketua kelompok peternak sapi PO Kebumen.

\section{MATERI DAN METODE}

Penelitian terkait kapasitas kepemimpinan dalam kelompok peternak Sapi PO Kebumen dilakukan menggunakan metode survey terhadap 147 peternak sapi PO Kebumen sebagai responden. Responden tersebut dipilih menggunakan metode sampling bertahap dengan pertimbangan populasi kelompok peternak dan peternak sapi PO Kebumen heterogen dan jumlahnya besar. Tahapan pertama dilakukan dengan memilih wilayah secara sengaja (purposive) pada wilayah pusat produksi sapi PO Kebumen.

Tahapan kedua, kelompok peternak dipilih secara acak sebanyak $25 \%$ dari jumlah kelompok peternak. Penelitian ini menggunakan 24 kelompok peternak sapi PO Kebumen sebagai obyek penelitian. Umar [7] menyatakan bahwa jumlah sampel yang dinilai cukup mewakili keseluruhan populasi yaitu minimal $10 \%$ dari total populasi. Tahapan selanjutnya peternak sapi PO Kebumen dipilih secara acak sebagai responden sebanyak 30\% dari jumlah anggota pada masing masing kelompok peternak terpilih. Responden diberikan 20 daftar pertanyaan untuk menilai kapasitas kepemimpinan ketua kelompok peternak sapi PO Kebumen. Pertanyaan di jawab dengan pendekatan skala likert 1-4 yaitu 1 untuk jawaban sangat kurang dan 4 untuk jawaban baik. Wawancara mendalam dengan daftar pertanyaan terstruktur digunakan untuk mendapatkan data dari responden. Data yang diperoleh dianalisis menggunakan statistik deskriptif dan korelasi ranking spearman.

\section{HASIL DAN PEMBAHASAN}

\section{Deskripsi kelompok peternak sapi PO Kebumen}

Kelompok peternak sapi PO Kebumen merupakan gabungan dari peternak peternak

Tabel 1. Profil kelompok peternak sapi PO Kebumen

\begin{tabular}{|c|c|c|c|c|}
\hline No & Profil & Kategori & Jumlah Kelompok & Persentase (\%) \\
\hline \multirow[t]{3}{*}{1} & Umur kelompok (tahun) & $<5$ & 0 & 0 \\
\hline & & $5-10$ & 10 & 41,67 \\
\hline & & $>10$ & 14 & 58.33 \\
\hline \multirow[t]{3}{*}{2} & Jumlah anggota (orang) & $<15$ & 1 & 4,17 \\
\hline & & $15-20$ & 17 & 70,83 \\
\hline & & $>20$ & 6 & 25,00 \\
\hline \multirow[t]{2}{*}{3} & Jumlah pertemuan/bulan & 1 & 22 & 91,67 \\
\hline & & $>1$ & 2 & 8,33 \\
\hline \multirow[t]{2}{*}{4} & Struktur anggota & Laki laki & 20 & 83,33 \\
\hline & & Laki laki dan wanita & 4 & 16,67 \\
\hline
\end{tabular}


sapi PO Kebumen yang memiliki tujuan sama dalam meningkatkan produksi sapi potong dan kesejahteraan peternak di Kabupaten Kebumen. Pada Tabel 1 dijelaskan bahwa kelompok peternak sapi telah melakukan kegiatan usaha ternak sapi potong dengan periode berkelompok pada kisaran 5-28 tahun dan rataan operasional kelompok 10,7 tahun. Hal tersebut menggambarkan bahwa kelompok peternak sapi PO Kebumen memiliki daya tahan yang memadai dan mampu bertahan sampai 10 tahun. Meuwissen et al. [8] menyatakan bahwa kemampuan petani dan usaha tani dalam bertahan lebih lama merupakan akumulasi tiga kapasitas ketahanan, kemampuan beradaptasi, dan kemampuan bertransformasi.

Sebagian besar kelompok (91,67\%) melakukan pertemuan rutin 1 kali per bulan dan sedikit kelompok yang melakukan pertemuan lebih dari 1 kali per bulan. Kelompok peternak dalam melakukan kegiatannya memiliki struktur organisasi yang memberikan gambaran penugasan kepada peternak sebagai komponen utama organisasi yaitu ketua, sekretaris, bendahara. Andersson et al. [9] menyatakan struktur organisasi kelompok yang seimbang dapat mendorong terwujudnya organisasi kelompok yang lebih tahan dan tanggung. Keseimbangan struktur organisasi dapat mengontrol distribusi kekuasaan dan mencegah hal hal yang tidak diinginkan.

Kelompok peternak sapi PO Kebumen merupakan kumpulan peternak peternak sapi PO Kebumen dengan latar belakang yang berbeda beda dan jumlah anggota yang beragam. Sebagian besar kelompok peternak (70,83\%) memiliki jumlah anggota 15-20 orang. Keterlibatan wanita dalam kelompok juga terlihat dalam usaha ternak sapi potong dan sebanyak 16,67\% kelompok memiliki anggota dengan jenis kelamin wanita dalam menjalankan proses usaha ternak sapi potong.

Faktor yang terkait dengan kapasitas kepemimpinan dalam kelompok peternak

Kapasitas kepemimpinan merupakan kemampuan seseorang pemimpin dalam mengelola kelompok dan anggotanya dalam mencapai tujuan kelompok. Upaya menemukan pemimpin yang sesuai untuk kelompok peternak di pedesaan tidak mudah dan kegagalan tersebut cenderung dapat mengakibatkan ketidakberlanjutan kelompok. Pemimpin dalam kelompok harus mampu membawa arah yang jelas tentang pergerakan kelompok, mengembangkan keberlanjutan kelompok, mengkoordinasikan hubungan dengan pihak eksternal dan menyelesaikan masalah. Sachs [10] menyatakan bahwa menemukan individu yang berkualitas dalam memenuhi kebutuhan pemimpin di suatu organisasi tidak mudah dan cenderung semakin sulit. Hallinger [11] menambahkan bahwa kapasitas pemimpin merupakan akumulasi kemampuan dalam merumuskan nilai nilai bersama dalam kelompok, memahami arah pengembangan organisasi, mengkordinasi antara input dan output serta merumuskan sistem penghargaan.

Kepemimpinan dalam kelompok peternak sapi PO Kebumen merupakan hal yang sangat penting dalam menggerakkan kelompok mencapai tujuannya. Keberadaan ketua kelompok yang memiliki kapasitas kepemimpinan yang memadai dapat menjadi modal penting dalam keberlanjutan kelompok. Ofuoku dan Agbamu [12] menyatakan bahwa kualitas kepemimpinan yang rendah dapat menghambat akses kredit, penentuan harga, dan penjualan produk ke konsumen. Oleh karena itu perlu di

Tabel 2. Profil ketua kelompok peternak sapi PO Kebumen

\begin{tabular}{llccc}
\hline No & \multicolumn{1}{c}{ Variabel } & Minimum & Maksimum & Rataan \\
\hline 1 & Umur (tahun) & 36,00 & 73,00 & 53,00 \\
2 & Tanggungan keluarga (orang) & 0,00 & 6,00 & 3,50 \\
3 & Pengalaman berkelompok (tahun) & 4,00 & 27,00 & 11,20 \\
4 & Pendidikan (tahun) & 6,00 & 16,00 & 11,95 \\
5 & Pengalaman beternak (tahun) & 6,00 & 52,00 & 27,83 \\
\hline
\end{tabular}


identifikasi faktor faktor untuk memperkuatnya agar proses produksi berlangsung lebih efektif.

Gambaran ketua kelompok sebagai pemimpin dalam kegiatan kelompok peternakan sapi PO Kebumen di peroleh dari 24 kelompok peternak sapi PO Kebumen. Karakteristik ketua kelompok peternak sapi PO Kebumen dapat dilihat pada Tabel 2.

Berdasarkan Tabel 2 digambarkan bahwa ketua kelompok memiliki rataan usia yang masih produktif (53 tahun). Ketua kelompok memiliki rataan pendidikan 12 tahun yang berarti mereka telah menyelesaikan pendidikan SMA. Ketua kelompok peternak sapi PO Kebumen memiliki rataan pengalaman berkelompok 11 tahun dan pengalaman beternak sapi potong 28 tahun. Kondisi tersebut menggambarkan peternak menjadikan usaha sapi potong sebagai budaya ternak yang dilakukan dengan basis kelompok.

Kapasitas kepemimpinan ketua kelompok peternak sapi PO Kebumen merupakan penilaian responden (anggota kelompok peternak) terhadap ketua kelompoknya dalam merencanakan, mengarahkan, memotivasi, dan menyelesaikan permasalahan kelompok. Ketua kelompok dari 24 kelompok peternak diberikan penilaian oleh 147 responden terhadap indikator kemampuan merencanakan pengembangan kelompok, mendorong inspirasi anggota, memberikan motivasi kepada anggota, memberikan penghargaan kepada angggota, memahami dan menyelesaikan permasalahan anggota berbasis musyawarah, dan kemampuan menjadi role model untuk anggota. Subasic et al. [13] menyatakan bahwa pemimpin harus memiliki kapasitas untuk mempengaruhi yang diperoleh dari legitimasi kekuasaan, pengalaman, dan keanggotaan pada kelompok rujukan serta sikap yang menyukai perubahan.

Berdasarkan Tabel 3 terlihat bahwa sebagian besar ketua kelompok peternak sapi PO Kebumen (91,67\%) memiliki kapasitas kepemimpinan yang tinggi.

Kondisi tersebut menggambarkan bahwa ketua kelompok peternak sapi PO Kebumen telah mampu merencanakan arah pengembangan kelompok peternak sapi $\mathrm{PO}$ Kebumen, menginspirasi dan memotivasi anggota peternak, serta menyelesaikan permasalahan kelompok. Kehadiran ketua kelompok dengan kapasitas yang memadai akan dapat meningkatkan atmosfer inovasi di dalam kelompok. Kemampuan anggota dalam berpikir kreatif dan inovatif dapat menyebabkan kelompok peternak lebih kuat dan berkelanjutan. Para anggota meningkat motivasinya karena diarahkan dalam mengatasi permasalahan permasalahan usaha sapi PO Kebumen. Hughes et al. [14] menyatakan bahwa kepemimpinan merupakan kunci kreatifitas dan inovasi anggota serta organisasi. Kreatifitas dan inovasi anggota akan mendorong kelompok peternak lebih maju dengan car acara usaha yang lebih baik dan berbeda seperti situasi normal. Hal tersebut di dukung pendapat Huang et al. [15] bahwa karakteristik dan kemampuan pemimpin memiliki hubungan yang nyata dengan kreatifitas anggota.

Kepemimpinan yang kuat dalam kelompok menjadi penting untuk upaya keberlanjutan usaha ternak sapi PO Kebumen. Terkait dengan hal tersebut, upaya upaya penguatan kapasitas kepemimpinan harus terus dilakukan melalui identifikasi faktor faktor strategis yang terkait dengan kapasitas kepemimpinan.

Berdasarkan analisis korelasi ranking spearman teridentifikasi bahwa kapasitas kepemimpinan ketua kelompok peternak

Tabel 3. Kapasitas kepemimpinan ketua kelompok peternak sapi PO Kebumen

\begin{tabular}{cccc}
\hline No & Skor tingkat kapasitas kepemimpinan & Jumlah (orang) & Persentase $(\%)$ \\
\hline 1 & $<13$ (rendah) & 0 & 0,00 \\
2 & $14-27$ (sedang) & 2 & 8,33 \\
3 & $>27$ (tinggi) & 22 & 91,67 \\
\hline & & 24 & 100,00 \\
\hline
\end{tabular}


terkait dengan umur ketua kelompok, pengalaman berkelompok, dan pengalaman beternak (Tabel 4).

Ketua kelompok peternak sapi PO Kebumen yang memiliki umur semakin tua menunjukkan kemampuan yang semakin meningkat dalam mengarahkan, menginspirasi, dan memotivasi anggota untuk mengembangkan kelompok $(\mathrm{P}<0,01)$. Selain itu kematangan pribadi ketua kelompok menyebabkan kemampuan ketua kelompok dalam menyelesaikan masalah semakin meningkat. Scheibe dan Zacher [16] menyatakan bahwa umur ketua kelompok sebagai pemimpin berpengaruh pada fungsi emosional dan perilaku yang ditunjukkan. Forgas and Bless [17] menambahkan bahwa pemimpin yang memiliki umur semakin dewasa akan memiliki lebih banyak pengetahuan dan pengendalian diri.

Pengalaman beternak sapi merupakan lama waktu sesorang peternak dalam menjalankan usaha ternak sapi dengan dinamika yang terjadi dalam proses produksi tersebut. Pengalaman beternak dapat membekali peternak memahami permasalahan dan merumuskan solusi terhadap permasalahan tersebut. Pengalaman beternak memiliki hubungan yang nyata $(\mathrm{P}<0,01)$ dengan kapasitas kepemimpinan kelompok. Pengalaman beternak sapi potong yang semakin lama mendorong ketua kelompok semakin percaya diri dan lebih mampu menyelesaikan persoalan anggota terkait dengan produksi sapi potong. Semakin lama pengalaman beternak yang dimiliki oleh peternak sapi PO Kebumen berdampak pada pengetahuan yang semakin meningkat terkait dengan usaha sapi potong. Kovac et al. [18] menyatakan bahwa pemimpin yang memiliki banyak pengetahuan dan informasi pada pekerjaan yang dilakukannya akan membuat lebih banyak upaya dibanding yang tidak memiliki pengetahuan. Pada saat yang sama hal tersebut akan menyediakan informasi yang bernilai dan mungkin dapat menjadi motivasi untuk anggotanya dalam melakukan kegiatannya. Martiskainen menambahkan bahwa kepemimpinan informal dalam masyarakat harus aktif mencari informasi terkait teknologi dan inovasi serta sumber pembiayaan. Pemimpin tersebut harus mampu membagi informasi dan pengetahuan dengan anggota.

Pengalaman berkelompok menggambarkan lama waktu ketua kelompok pernah terlibat dalam kegiatan kelompok usaha tani. Lama waktu keterlibatan tersebut memberikan dampak penguatan pengetahuan, sikap dan ketrampilan seseorang tentang kelompok. Berdasarkan analisis korelasi rank spearman terlihat bahwa pengalaman ketua kelompok menjadi bagian dari kelompok sebagai anggota ataupun ketua kelompok yang semakin lama menyebabkan ketua kelompok peternak sapi PO Kebumen memiliki kapasitas kepemimpinan yang semakin meningkat $(\mathrm{P}<0,05)$. Hartviksen et al. [20] menyatakan bahwa pengalaman mengelola organisasi dan membangun jaringan (network) menjadi faktor penting dalam meningkatkan kapasitas pemimpin dalam mengelola organisasi. Hal ini didukung oleh Bartol dan Zhang [21] bahwa pengembangan kapasitas kepemimpinan memerlukan kemampuan membangun hubungan interpersonal. Kemampuan tersebut akan menambah dan mengembangkan jaringan, modal sistem,

Tabel 4. Faktor faktor yang terkait dengan kapasitas kepemimpinan ketua kelompok peternak sapi PO

\begin{tabular}{clcc}
\multicolumn{1}{c}{ Kebumen } & Kariabel & Koefisien korelasi & Signifikansi \\
\hline No & & 0,546 & $\mathrm{P}<0,01$ \\
\hline 1 & Umur & $-0,010$ & $\mathrm{P}>0,05$ \\
2 & Tanggungan keluarga & 0,477 & $\mathrm{P}<0,05$ \\
3 & Pengalaman berkelompok & 0,075 & $\mathrm{P}>0,05$ \\
4 & Pendidikan & 0,866 & $\mathrm{P}<0,01$ \\
5 & Pengalaman beternak & & \\
\hline
\end{tabular}


modal sosial dan modal manusia.

Tanggungan keluarga dan pendidikan ketua kelompok peternak sapi PO Kebumen tidak memiliki keterkaitan yang nyata $(\mathrm{P}>0,05)$ dengan kapasitas kepemimpinan ketua kelompok. Banyaknya anggota keluarga yang dimiliki ketua kelompok peternak tidak memberikan memberikan perbedaan kapasitas kepemimpinan dalam kelompok. Pendidikan formal yang dimiliki ketua kelompok peternak sapi PO Kebumen tidak menunjukkan keterkaitan dengan kemampuan ketua kelompok dalam mengarahkan dan memotivasi anggota untuk mengembangkan usaha ternak.

\section{KESIMPULAN}

Ketua kelompok peternak sapi PO Kebumen memiliki kapasitas kepemimpinan yang tinggi. Umur ketua kelompok, pengalaman beternak, dan pengalaman berkelompok memiliki keterkaitan yang nyata terhadap kapasitas kepemimpinan dalam kelompok peternak sapi PO Kebumen.

\section{KONFLIK KEPENTINGAN}

Penulis menayatakan tidak ada konflik kepentingan dengan pihak manapun terkait materi yang ditulis dalam naskah ini.

\section{DAFTAR PUSTAKA}

1. Sugiarto, M., S. Nur, Djatmiko OE, and Gayatri S. 2019. Discrepancy, and spatial grouping of individual potential among Kebumen Ongole Grade cattle farmers in Kebumen Regency. J. Indonesian Trop. Anim. Agric. 44:195-203. doi:10.14710/jitaa.44.2.195-203.

2. Rustinsyah R. 2019. The significance of social relations in rural development: A case study of a beef-cattle farmer group in Indonesia. J. Co-op. Organ. Manag. 7:100088. doi:10.1016/j.jcom.2019.100088.

3. Suheimi, D., A. Fatchiya, and S. Harijati. 2019. Faktor-faktor yang mempengaruhi dinamika kelompok di Kabupaten Cirebon. Jurnal Penyuluhan. 15:97-110. doi:10.25015/penyuluhan.v15i1.21861.
4. Uhl-Bien, M. and M. Arena. 2018. Leadership for organizational adaptability: A theoretical synthesis and integrative framework. Leadersh. Q. 29:89-104. doi:10.1016/j.leaqua.2017.12.009.

5. Surji, M. K. 2013. Understanding leadership and factors that influence leaders' effectiveness. Eur. J. Bus. Manag. 7:154-167. doi:10.7176/EJBM/7-33-2015-03.

6. Dubrin, A. J. 2007. Leadership: research findings, practice and skills. Houghton Mifflin Company, New York.

7. Umar, H. 2005. Metode penelitian untuk bisnis. Raja Grafindo Persada, Jakarta.

8. Meuwissen, M. P. M., P. H. Feindt., A. Spiegel, C. J. A. M. Termeer, E. Mathijse, Y. de Mey, R. Finger, A. Balmann, E. Wauters, J. Urquhart, M. Vigani, K. Zawalińska, H. Herrera, P. Nicholas-Davies, H. Hansson, W. Paas, T. Slijper, I. Coopmans, W. Vroege, A. Ciechomska, F. Accatino, B. Kopainsky, M. Poortvliet, J. J. L. Candel, D. Maye, S. Severini, S. Senni, B. Soriano, C. J. Lagerkvist, M. Peneva, C. Gavrilescu, and P. Reidsma. 2019. A framework to assess the resilience of farming systems. Agric. Syst. 176. doi:10.1016/j.agsy.2019.102656.

9. Andersson, T., M. Cäker, S. Tengblad, and M. Wickelgren. 2019. Building traits for organizational resilience through balancing organizational structures. Scand. J. Manag. 35:36-45. doi:10.1016/j.scaman.2019.01.001.

10.Sachs, J. 2004. The problem of the principalship: attracting people to difficult jobs. In R. H. Ahmad and T. F. Hee (Eds.), Principalship and School Management, Principals' Institute, Faculty of Education, University of Malaya, Kuala Lumpur.

11. Hallinger, P. 2005. Instructional leadership and the school principal: A passing fancy that refuses to fade away. Leader. Pol. Schools. 4:221-240.

12. Ofuoku, A. U. and J. U. Agbamu. Leadership effectiveness among farmers' self-help groups in Central Agricultural Zone of Delta State, Nigeria and its implication for improved agricultural extension service. Asian J. Agric. Ext. Econ. Sociol. 2:41-53. doi:10.9734/AJAEES/2013/2869. 
13. Subasic, E., K. J. Reynolds, J. C. Turner, K. E. Veenstra, and S. A. Haslam. 2010. Leadership, power and the use of surveillance: Implications of shared social identity for leaders' capacity to influence. Leadersh. Q. 22:170-181. doi:10.1016/j.leaqua.2010.12.014.

14. Hughes, D. J., A. Lee, T. A. Wei, A. Newman, and C. Knight. 2018. Leadership, creativity, and innovation: A critical review and practical recommendations. Leadersh. 29:549-569. doi:10.1016/j.leaqua.2018.03.001.

15. Huang, L., D. V. Krasikova, and D. Liu. 2016. I can do it, so can you: The role of leader creative self-efficacy in facilitating follower creativity. Organ. Behav. Hum. Decis. Process. 132:49-62. doi:10.1016/j.obhdp.2015.12.002.

16. Scheibe, S. and H. Zacher. 2013. A lifespan perspective on emotion regulation, stress, and well-being in the workplace. In P. L. Perrewé, J. Halbesleben, \& C. C. Rosen (Eds.), Res. Occup. Stress Wellbeing. 11:167-197. doi:10.1108/S1479-3555(2013)0000011010.

17. Forgas, J. and H. Bless. 2006. Affect in social thinking and behavior. (12 ${ }^{\text {th }}$ ed.). Psychology Press, New York.

18. Kovac, H., M. Sirol, and M. Sumanjski. 2017. Leadership handbook. South East European Youth Network, Sarajevo, Bosnia and Herzegovina.

19. Martiskainen, M. 2016. The role of community leadership in the development of grassroots innovations. Environ. Innov. Soc. $\quad$ Tr. 22:78-89. doi:10.1016/j.eist.2016.05.002.

20. Hartviksen, T. A., B. M. Sjolie, J. Aspfors, and L. Uhrenfeldt. 2018. Healthcare middle managers` experiences developing leadership capacity and capability in a public funded learning network. BMC Health. Serv. Res. 18:433. doi:10.1186/s12913-018-3259-7.

21. Bartol, K. M. and X. Zhang. 2007. Networks and leadership development: Building linkages for capacity acquisition and capital accrual. Hum. 17:388-401. doi:10.1016/j.hrmr.2007.08.004. 